\title{
Diamonds in ultrabasic rock near Wawa, Ontario, Canada
}

Thomas, R.D., Novak, N.A. and Janse, A.J.A.

Spider Resources Inc., Suite 2100, 121 King Street West, Toronto, Ont., Canada M5H 3T9

A new type of diamondiferous rock was discovered in September 1995 by Sandor Surmacz and Marcelle Hauseux, an independent prospector and a geologist who form a partnership by the name of Saminex, based in Toronto. The original Sandor Diamond Occurrence, as it now called, is located in a roadcut along highway 17 , approximately $30 \mathrm{~km}$ north of Wawa, in Lalibert township at $48^{\circ} 12^{\prime} 57^{\prime \prime} N$ and $84^{\circ} 50^{\prime} 46^{\prime \prime} \mathrm{W}$. Saminex brought this occurrence to the attention of Spider Resources Inc. of Toronto which collected additional samples and confirmed the occurrence of diamonds in this rock in the first news release dated June 25, 1996. The original discovery by Saminex of six diamonds in an $18 \mathrm{~kg}$ sample, processed by the Saskatchewan Research Corporation of Saskatoon, Saskatchewan, was corroborated by the $67.6 \mathrm{~kg}$ sample collected by Spider and processed by caustic dissolution by Lakefield Research of Peterborough, Ontario, which produced 64 diamonds, of which eight were larger than $0.5 \mathrm{~mm}$. The diamonds are classified as containing 83 $\%$ white, colourless stones and $85 \%$ of the total are broken crystals (Spider Resources news release September 23, 1996).

The rock from which the diamonds is made up of a very hard and tough matrix consisting of densely-packed actinolite containing numerous round xenoliths made up of needles of actinolite radiating from the centre. The xenoliths are slightly harder than the matrix and thus stand out distinctly in the rock face. Many xenoliths are surrounded by a wide, brownish-yellowish reaction rim of actinolite and talc. Under the microscope the matrix consists mainly of amphibole of the actinolite-tremolite series with minor amounts of biotite and albite. Accessory minerals are sphene, apatite, rare epidote and very rare magnetite. The xenoliths consist of actinolite with minor biotite and calcite and accessory spinel, ie.hercynite-chromite, not a relict primary mineral (Mitchell, 1996, in-house report). The protolith is unknown as no primary minerals are preserved (the xenoliths may possibly have been pyroxenite, Mitchell, 1996, in-house report) and has been subjected to retrograde lower greenschist metamorphism which is pervasive in the surrounding Archaean country rocks. At the Sandor Diamond Occurrence contacts with the Archaean wall rock appear conformable within the dimensions of the outcrop and deformation is slight with a penetrative fabric consistent in direction and nature with the Archaean wall rock. In other outcrops it looks like a dyke with slightly sheared crosscutting contacts in places but all other above mentioned characteristics are similar. From these observations it is concluded that the diamondiferous rocks are Archaean, or at least Palaeoproterozoic in age, which is much older than that of the lamprophyric dykes found south of Wawa (see below).

An exploration program carried out in July and August 1997 collected 103 rock samples and 367 till samples. The most significant result came from an outcrop along highway 17 in Menzies township, $5 \mathrm{~km}$ south of the original Sandor Diamond Occurrence. The sample was taken from newly broken rock from the back of the roadcut, freshly stripped and washed prior to sampling to alleviate all concerns about contamination from previous road work. A total of 95 diamonds, including 15 diamonds larger than $0.4 \mathrm{~mm}$, were recovered from a $164.7 \mathrm{~kg}$ sample. The largest diamond is a white, colourless transparent fragment measuring $0.82 \mathrm{~mm}$ by $0.76 \mathrm{~mm}$ by $0.65 \mathrm{~mm}$. A very tentative, preliminary grade for all diamonds down to $0.1 \mathrm{~mm}$ from $193 \mathrm{~kg}$ of rock can be estimated at 25 carats per 100 tonnes. The containing rock at this outcrop is a $3 \mathrm{~m}$ wide, steeply dipping, xenolith-rich mafic to ultramafic dyke crosscutting Archaean felsic and agglomeratic tuffs. 
However, the penetrative fabric consistent with the surrounding wall rock suggests an Archaean to Palaeoproterozoic age of formation.

A total of 196 diamonds has been recovered from the nine sites tested todate. Results for the remaining samples have not yet been tabulated. No valuation of the recovered diamonds has been attempted as yet, so it is too early to determine the economic significance of this new discovery. Moreover, the extent of the diamondiferous rock outcrops and the origin of the diamonds has not yet been established.

Already in 1975 Janse noticed xenolith-rich rocks along highway 17 which he described as xenolith-rich mafic volcanics (Janse, personal field notes, 1975). They were also noticed by Sage in the 1980's during geological mapping of Lalibert township and described as intrusive breccias, dykes and sills. However, the significance of microdiamonds for diamond exploration was not yet understood at the time and facilities for microdiamond recovery were not yet available so that no further work was planned for these rocks.

Lamprophyric dykes of Keweenawan age (1200 to $1000 \mathrm{Ma}$ ) are common in an area south of, and closer to, Wawa, south of the Wawa Lake-Hawk Lake-Manitowik Lake fault zone (Sage and Crabtree, 1997). Compared to Archaean rocks, the lamprophyres appear quite fresh where exposed in road cuts, river banks/cliffs and mine cuts.

An olivine-rich dyke containing numerous small bean-sized spinel-harzburgite xenoliths, located along highway 17 , approximately $10 \mathrm{~km}$ south of Wäwa and $1 \mathrm{~km}$ south of the highway bridge across the Michipicoten River, was found by Janse in 1975 and described by Mitchell and Janse (1982). The matrix contains olivine, clinopyroxene, phlogopite and analcite, and the xenoliths olivine, orthopyroxene and spinel. It was classified as an ultramafic lamprophyre close to monchiquite. The authors suggested that the occurrence of this dyke indicated the possible presence of deep-reaching faults in the Wawa area which might be conducive for diamondiferous intrusives. Mickey Clement, a local prospector, claimed to have found two diamomds in the lower course of the Michipicoten River in approximately 1991. Thiese stones were identified by the Royal Ontario Museum as diamonds of respectively, 1.05 and 1.13 carats (Sage and Crabtree, 1997). Subsequent prospecting by Morris of the OGS found kimberlite indicator minerals, including G-10 garnets, in many alluvial sites in the general area (Morris et al, 1994). In August 1995 Terry Nicholson, a local prospector, found the "Nicholson Dike", an ultramafic lamprophyre, resembling in overall mineralogy and chemistry the monchiquite dyke found by Janse in 1975 (Sage and Crabtree, 1997). However, the Nicholson dyke is wider and longer and contains many xenoliths of garnetharzburgite, garnet-lherzolite, spinel-harzburgite and eclogite. Its age of formation is approximately $1100 \mathrm{Ma}$ (Sage and Crabtree, 1997). Several companies have tested the dyke for diamonds without positive results. Mineralogical investigation by Sage and Crabtree (1997) indicated that the lilaccoloured garnets of the Nicholson dyke were not similar to the G-10 garnets found by Morris during his alluvial survey, so that the source of the alluvial indicator minerals is still unknown. However, an unusual pyroxene-bearing kimberlite in the James Bay Lowland with a similar age of formation as the Nicholson dyke is significantly diamondiferous (Janse, Novak and McFadyen, 1995) which suggest that there was a diamondiferous intrusive event at this age in Ontario.

The appearance of many of the lamprophyres, especially the Nicholson dyke with its many mantle xenoliths, superficially resembles that of kimberlites and may be mistakenly identified as such by prospectors. Hence the reports of the discovery of kimberlites in the Wawa area. They are, however, not kimberlites, but ultramafic lamprophyres or alnoites, similar to what Dawson once described as "central-complex kimberlites". The central complex in this case is the Firesand carbonatite which occurs under overburden $7 \mathrm{~km}$ east of Wawa.

The diamondiferous ultramafic rocks, 25 to $30 \mathrm{~km}$ north of Wawa, are not related in mineralogy or age to the lamprophyre dykes nearer to Wawa and their origin is still unknown. 


\section{References:}

Janse, A.J.A., Novak, N. A. and MacFadyen, D.A., 1995, Discovery of a new type of highly diamondiferous kimberlitic rock in the James Bay Lowlands, northern Ontario: In Extended Abstracts Sixth International Kimberlite Conference, United Institute of Geology, Geophysics and Mineralogy, Siberian Branch of the Russian academy of Sciences, Novosibirsk, p. 260-262.

Mitchell, R.H. and Janse, A.J.A., 1982, A harzburgite-bearing monchiquite from Wawa, Ontario: Canad. Mineralog., 26, p. 211-216.

Morris, T.F., Murray, C. and Crabtree, D., 1994, Results of overburden sampling for kimberlite heavy mineral indicators and gold grains, Michipicoten River-Wawa area, northeastern Ontario: Ontario Geol. Surv., Open file report 5908, 69 p.

Sage, R.P. and Crabtree, D., 1997. The "Nicholson" ultramafic dike, Wawa, Ontario: a preliminary investigation: Ontario Geol. Surv., Open file report 5955, 111 p.

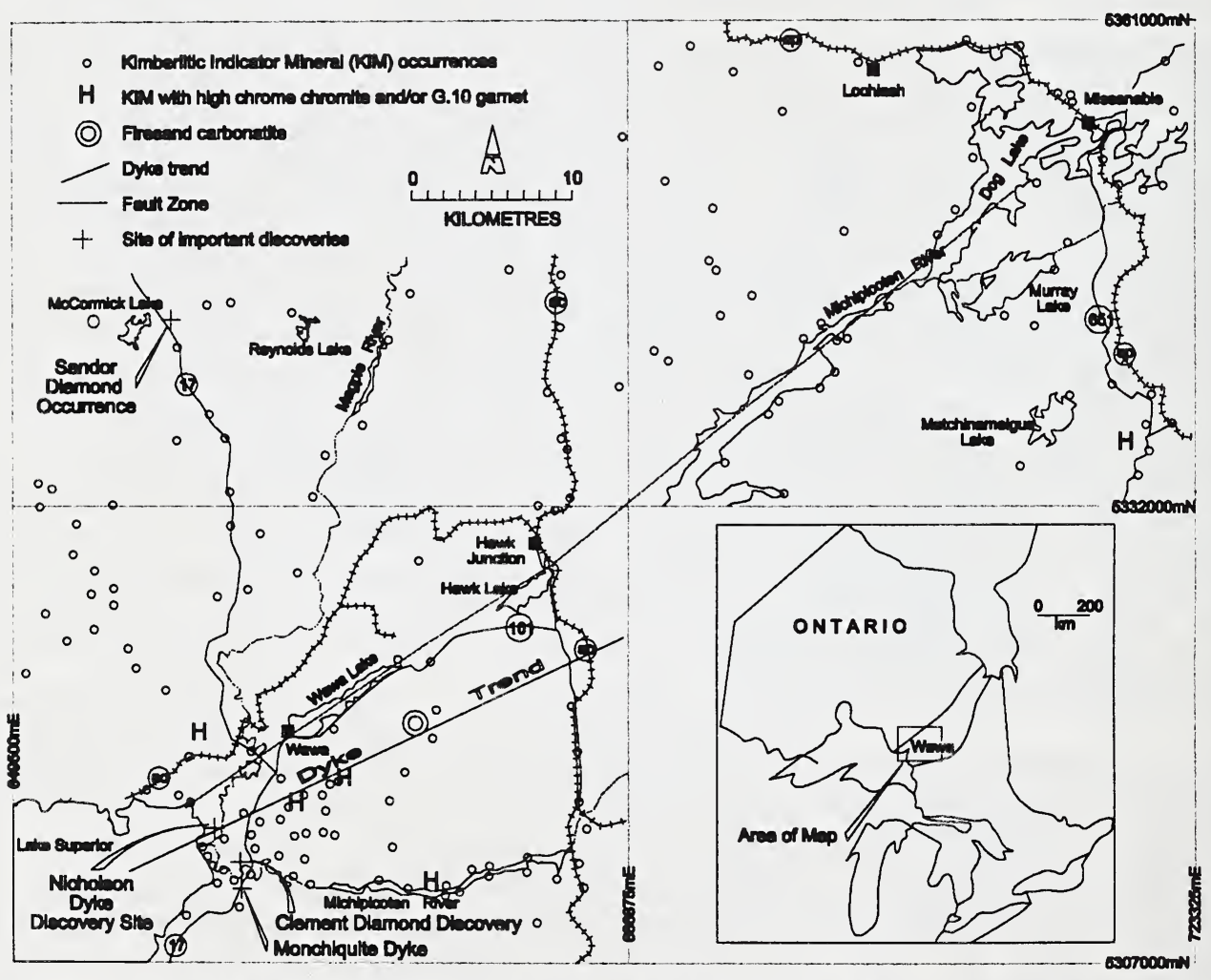

LOCATION MAP OF THE WAWA ULTRAMAFIC ROCKS. LAMPROPHYRES AND KIMBERLITE INDICATOR MINERALS (after Morris et al, 1994) 